\title{
GEOGRAPHIC SCENARIO OF DRINKING WATER QUALITY OF LAHORE METROPOLITAN, PAKISTAN, IN RESPONSE TO URBANIZATION AND WATER DEMAND: A GIS PERSPECTIVE
}

\author{
BATOOL, R. ${ }^{1,2}-$ MAHMOOD, K..$^{2 *}$ AHMAD, S. R. ${ }^{1}-$ NAEEM, M. A. ${ }^{3}$ \\ ${ }^{1}$ College of Earth and Environmental Sciences, University of the Punjab, Lahore, Pakistan \\ (e-mail: ridabatool1214@gmail.com) \\ ${ }^{2}$ Department of Space Science, University of the Punjab, Lahore, Pakistan \\ ${ }^{3}$ Department of Electrical Engineering, University of the Punjab, Lahore, Pakistan \\ *Corresponding author \\ e-mail: khalid.m270@yahoo.com, khalid.spsc@pu.edu.pk; phone:+92-321-402-5836
}

(Received $9^{\text {th }}$ Nov 2018; accepted $8^{\text {th }}$ Feb 2019)

\begin{abstract}
This study is intended to evaluate and segregate potential zones of groundwater quality over residential area of Lahore, Pakistan, where population growth and modernization of urban infrastructure are exerting pressure on finite groundwater resources. The study is based on the groundwater quality data of the year of 2016, with physicochemical quality parameters of total dissolved solids (TDS) potential hydrogen $(\mathrm{pH})$, calcium $(\mathrm{Ca})$, chlorine $(\mathrm{Cl})$, magnesium $(\mathrm{Mg})$ and bicarbonates $\left(\mathrm{HCO}_{3}\right)$. Optimal spatial interpolation methods are applied to generate continuous information of all quality parameters using geospatial techniques. Each thematic map of quality parameter has been classified using standard laid down by World Health Organization (WHO). A brief spatial analysis of given quality parameters has been made with reference to their possible source and underground movement. Then, all parameters are overlaid to generate a single indicator of water quality in form of water quality index (WQI) that has been used for segregation of groundwater quality zones. An insight analysis of the spatial pattern of WQI has shown that urban expansion in the southeastern region of study area that has been transformed from agricultural land to impervious surface is the reason behind increased concentration of contaminants in local groundwater. Other prominent zones of contaminated groundwater are found near regions of Anarkali and Gulberg.
\end{abstract}

Keywords: groundwater quality, geographic information system, spatial interpolation, spatial analysis, water quality index

\section{Introduction}

Water is one of the primary natural resources to all existing living bodies and ecological systems on earth. Today, preservation of pure water has become a serious issue to maintain healthy environment and economic growth on earth (Ojo et., 2007; Postel et al., 1996). Domestic water demand is increasing day by day with the evaluation in the modern living culture commonly in most of the densely populated urban regions of the world. Over 2.5 billion people in the world have no access to proper sanitation and quality drinking water that costs in deaths of over 1.8 million people, annually (Shrivastava et al., 2015; WHO and UNICEF, 2013a; WHO, 2002). In general, a challenging situation has been driven out due to uncertain atmospheric conditions and lack of decision making by the world leading powers (Interpress, 1999; Shrivastava et al., 2015). In developing countries, including Pakistan, decreasing precipitation rates are ultimately affecting the conservation of freshwater resources (Azizullah et al., 2011). United Nations International Children's Emergency (UNICEFF) and Environmental Protection Agency (EPA) have reported an alarming 
situation in the main cities of Punjab where high proportions of toxic arsenic have been observed in drinking water (WWF, 2007). In Lahore city, provincial capital of Punjab, aquifer recharge has been reduced due to high abstraction rates of groundwater (Muhammad and Zhonghua, 2014). Water is a good solvent, having strong hydrogen bonding and distinctive nature of polarization it can dissolve many bacterial and natural components. Therefore, naturally occurring water always get polluted through anthropogenic as well as biological activities over and under the surface (Chitmanat and Traichaiyaporn, 2010; Khattak et al., 2012; Mendie, 2005). Today most of the studies regarding groundwater quality assessment are being conducted to highlight sources of contamination behind groundwater pollution in a region. Usually, natural processes of rock-water interactions, precipitation rates and anthropogenic activities like extensive use of fertilizers, disposal of wastes and intrusion of salts are general causes of groundwater contamination (Kumar et al., 2011). Nature of groundwater pollution sources can be categorized in point sources and non-point sources. Point sources are such distinct spots which spread pollutants directly like septic container etc. Whereas non-point sources are diffused sources of contamination that could be in form of fertilizers used over a wide spread agricultural land. As, groundwater flows from recharged regions to discharge areas because of gravity. So, high rates of groundwater withdrawal from certain regions tends towards the aquifer depletion of whole of the area (Siebert et al., 2010). TDS is key standard of drinking water quality and it is used to determine saline properties of groundwater. Presence of salts and slight number of organic components in water can change the groundwater quality. Such constitutes of salts either organic or inorganic are soluble in water in form of magnesium, calcium, sodium, potassium cations and their carbonates (WHO, 2003). Weathering of rocks is another cause of rising concentration of bicarbonates in the groundwater that could be either physical, chemical or biological (Mohsin et al., 2013). Successive natural weathering of rocks, decomposition of multiple salt rocks and percolation through soil significantly rise the chlorine concentration level in groundwater (Sivakumar et al., 2000). Calcium is insoluble in water, but its high concentrations in the presence of magnesium can cause hardness of the water (WHO, 2009). Alkaline or acidic nature of groundwater can be computed by $\mathrm{pH}$, which is one of common indicator to describe the $\mathrm{pH}$ level. Values ranges from 7-1 reflects acidic nature and alkaline nature of groundwater is taken more than 7 (WHO, 2007). Ultimately, intrusion of pollutants into the steadily flowing water generate a downslope plume. Such plume elongates through its point source up to the several kilometres and contaminate the water body or groundwater recharge source (Montgomery, 2011). A preview of studies suggests that multivariate spatial techniques are useful to interpret spatial variability of different environmental variables (Mahmood et al., 2011; Sharaf and Sabyani, 2011). Geographic Information System (GIS) offers a complete set of tools to identify the spatial extent of groundwater variability and interpretation of groundwater quality over concerned area. It also helps to evaluate potential regions through variety of operational tools to examine the consequences behind the variability (Mahmood et al., 2016). Spatial interpolation is an artistry tool commonly used to analyze the variability by creating a continuous surface of estimated values from limited known sample data values. Different models and complex mathematical functions are operated to generate optimal output surfaces under the GIS environment (Batool et al., 2015). It also helpful to generate water quality index (WQI) for an overall groundwater quality assessment by using single number or grade based upon locational data of different water quality 
parameters. WQI converts complex data values into the user-friendly information for the public awareness and policy makers to make better decisions regarding water resource management (Shabbir and Ahmad, 2015). Asadi et al. (2007) have concluded the use of GIS as effective toolset for calculating groundwater quality index (GWQI). Overall results show that most of the study area is in permissible limits for drinking water, as defined by WHO. Nas and Berktay (2010) investigated the groundwater conditions in the area of Konya city using the same handy toolset of GIS. In the study thematic maps of different physical and chemical water quality parameters were critically analyzed to elaborate the decreasing trend of groundwater quality from south to north of the city. Adnan and Iqbal (2014) have performed physicochemical analysis for groundwater quality assessment to explore the spatial distribution of water quality parameters over the region of Peshawar, Pakistan. They have obtained spatial surfaces using Inverse Distance Weighted (IDW), as the interpolating function without checking accuracy with other available options. A comparison of different deterministic and stochastic interpolation techniques was explained by Gunarathna et al. (2016), for mapping $\mathrm{pH}$ concentrations in the region of Malwathu Oya cascade-I, Sri Lanka. It was justified that stochastic methods give more precise results for the spatial analysis of $\mathrm{pH}$ values in groundwater of the study area (Gunarathna et al., 2016). It has highlighted the importance of exploring all the interpolation techniques to generate most reliable prediction surfaces. Current study is designed to analyze groundwater quality trends in the potential zones of Lahore with an emphasis that how rapid urbanization and growing economic development effect on groundwater quality and cause water pollution.

\section{Materials and methods}

\section{Study area}

Lahore is the most dynamic metropolitan of the province Punjab, Pakistan. Geographically it is extended $31^{\circ} 15^{\prime}$ to $31^{\circ} 45^{\prime}$ in north and $74^{\circ} 01^{\prime}$ to $74^{\circ} 39^{\prime}$ in east over Asian plate. Lahore is surrounded by district Sheikhupura in north and easterly bordered with India (Muhammad and Zhonghua, 2014). At northwest edge, a prominent river course exists named as River Ravi which acts like administrative boundary between Sheikhupura and Lahore district, as given in Figure 1. Fresh water demand has become a big concern of the study area due to overpopulation, modern urban infrastructure and accelerated economic transformation rate (Shah and Abbas, 2017). Latest Censusreport of Pakistan has shown that population of Lahore district has been reached to 11.13 million with an average annual growth rate of $4.07 \%$ (Pakistan Bureau of Statistics, 2017). Seasonal variations in temperature patterns and precipitation rates have decreased rainfall in Lahore. In hot summer, temperature rises from $40{ }^{\circ} \mathrm{C}$, whereas in winter it reaches up to $5{ }^{\circ} \mathrm{C}$. Monsoon period contributes almost up to $40 \mathrm{~mm}$ in groundwater recharge with approximately $75 \%$ precipitation per year (Dogar, 2008; Muhammad and Zhonghua, 2014). Various studies have revealed that unconciliated alluvial deposits have made Lahore's aquifer unconfined, highly permissible and more substantial (Kanwal et al., 2015). Although, River Ravi accomplishes the water demand of the whole city but its condition is going worse day by day. With decreasing rain water runoff, it receives approximately $47 \%$ of the total municipal and industrial waste of the city which have been voided into it without any treatment (Akhtar et al., 2014). Extensive digging for the construction of deep surface infrastructure like underground bus systems and pillar bases for overhead bridges has 


$$
\text { - } 3976 \text { - }
$$

been observed to provide a temporarily increased groundwater recharge, showing importance of local recharge in sustainability of this precious source of drinking water (Mahmood and Tariq, 2017; Wateraid and BGS, 2009). Ultimately, degradation of groundwater quality has caused serious health related issues in nearby areas (Basharat and Rizvi, 2011). Domestic and industrial needs of water are being fulfilled by pumping out groundwater either by the private societies and industries or government authorities. More than 500 production wells have been installed by Water and Sanitation Agency (WASA), Lahore to supply water to 531,336 connections in the mega city. WASA, Lahore also monitors groundwater quality by examining its chemical, physical and bacterial properties to ensure the availability of pure water (Akram and Gabriel, 2007; Basharat and Rizvi, 2011).

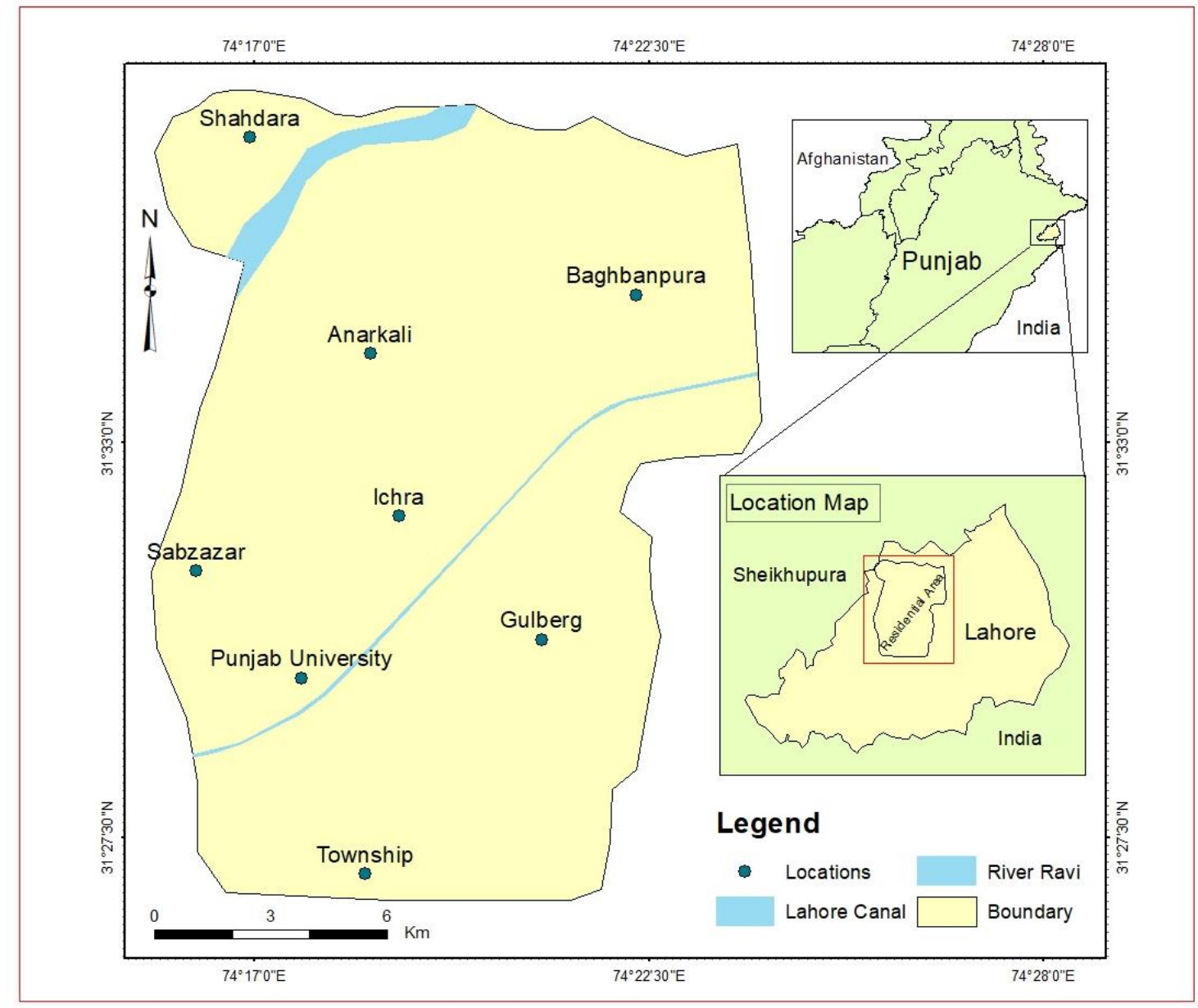

Figure 1. Study area

\section{Data collection}

Groundwater quality assessment of a region can be conducted by using multiple analytic approaches. In the present study, 200 water samples have been collected from installed tub wells by WASA in different regions of the district Lahore in the year of 2016, as presented in Figure 2. Sample data consists of limited quality parameters, Calcium $(\mathrm{Ca})$, Chlorine $(\mathrm{Cl})$, Bicarbonates $\left(\mathrm{HCO}_{3}\right)$, Magnesium $(\mathrm{Mg}), \mathrm{pH}$ and Total 


$$
-3977 \text { - }
$$

Dissolved Solids (TDS) which were chemically analyzed in Water Quality Laboratory WASA, Lahore. All the collected samples have been chemically examined through different titration techniques recommended by American Public Health Association (APHA) and World Health Organization (WHO). $\mathrm{pH}$ values are calibrated through buffer solution of 7,8 and 9 and alkalinity has been measured through acid-base titration method due to the presence of calcium and magnesium components. Geographic coordinate data of each sample location were collected through a GPSmap$76 \mathrm{Sx}$, with an accuracy of approximately $3 \mathrm{~m}$ by field survey. All the sample data values and their location data have been combined in excel sheet. Further geographic coordinates have been assigned to assembled data and displayed in the ArcGIS 10.1 to generate a geographic layer. General statistical characteristics of each Groundwater quality parameters have been mentioned in Table 1. Different spatial interpolation techniques (Deterministic and Stochastic Methods) have been assessed to evaluate the spatial variability of water quality parameters over the study area.

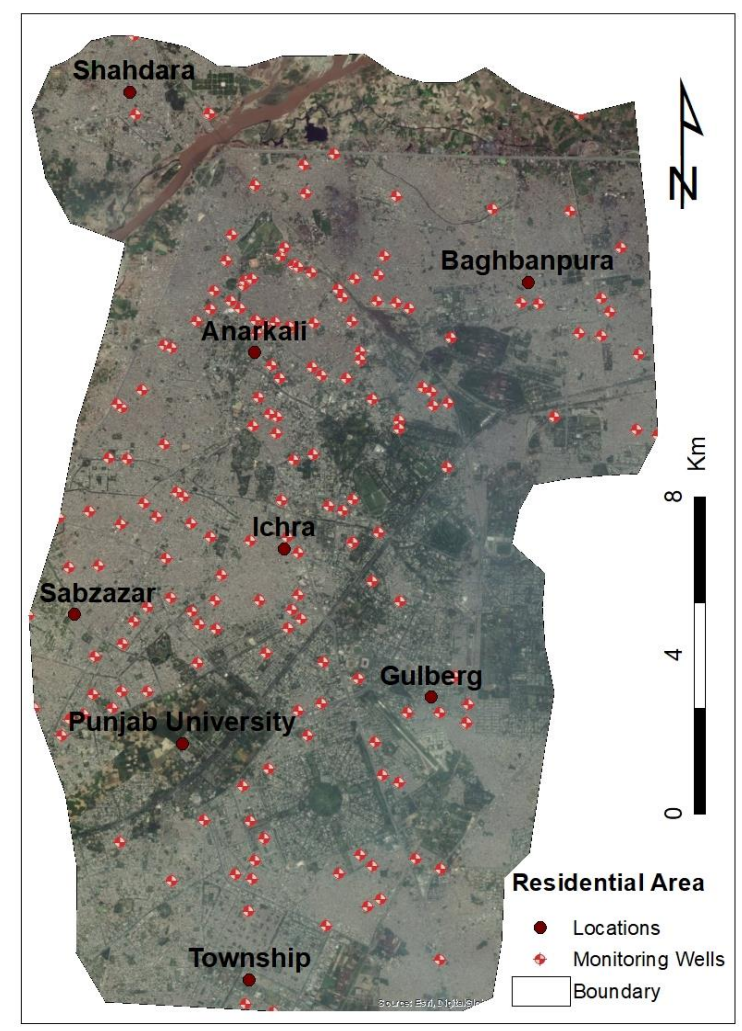

Figure 2. Production wells in residential area of Lahore

Table 1. General statistics of selected groundwater quality parameters

\begin{tabular}{c|c|c|c|c|c}
\hline Water quality parameters & Mean & Median & Maximum & Minimum & Std. \\
\hline Calcium (mg/L) & 32.56 & 29.20 & 87.20 & 05 & 15.60 \\
Chlorine (mg/L) & 47.82 & 37 & 260 & 15 & 33.69 \\
HCO3 (mg/L) & 232.83 & 214 & 506 & 94 & 79.68 \\
Magnesium (mg/L) & 19.79 & 16.80 & 65.30 & 5.60 & 11.16 \\
pH (Value) & 7.87 & 7.80 & 8.30 & 7.80 & 0.11 \\
TDS (mg/L) & 424.16 & 381.10 & 988.40 & 173.20 & 190.8 \\
\hline
\end{tabular}




\section{Spatial interpolation}

Geo-statistical techniques help to analyze spatial continuity and therefore have been used by most of groundwater studies, especially those which have used geographically unevenly distributed sample data. Spatial interpolation techniques are based on the first law of Geography which states that closer objects are more similar than those that are far apart (Batool et al., 2015). Inverse Distance Weighted (IDW) is being used since a long time in many studies which now has been replaced by advance methods of Kriging (Mahmood et al., 2016). IDW method interpolates through assigning weights, depending upon mutual distances between sample data values using a power function. Optimized power values define the influence of each quality parameters over the region in generating a continuous surface. On the other hand, kriging family get the real surfaces by using probabilistic function like semivariogram and its different models. Kriging have three main types, i.e. Ordinary Kriging, Simple Kriging and Universal Kriging that are based on the complex functions (Javari, 2017). Each spatial interpolation technique has its own significance; therefore, each of them has been applied to the current dataset to optimize the best predicted results. Accuracy of each method is measured and assessed using Root Mean Square Error (RMSE) which has been mentioned in Table 2.

Table 1. Comparison of different interpolation methods by using RMSE values

\begin{tabular}{c|c|c|c|c|c|c}
\hline $\begin{array}{c}\text { Water quality parameter } \\
\text { optimal interpolation methods }\end{array}$ & $\begin{array}{c}\text { Calcium } \\
(\mathbf{m g} / \mathbf{L})\end{array}$ & $\begin{array}{c}\text { Chlorine } \\
(\mathbf{m g} / \mathbf{L})\end{array}$ & $\begin{array}{c}\mathbf{H C O} \\
(\mathbf{m g} / \mathbf{L})\end{array}$ & $\begin{array}{c}\text { Magnesium } \\
(\mathbf{m g} / \mathbf{L})\end{array}$ & $\mathbf{p H}$ & $\begin{array}{c}\text { TDS } \\
(\mathbf{m g} / \mathbf{L})\end{array}$ \\
\hline IDW & 14.590 & 28.782 & 70.644 & 10.117 & 0.102 & 153.668 \\
Global polynomial & 14.877 & 32.392 & 65.464 & 10.058 & 0.105 & 169.060 \\
Local polynomial & 14.513 & 29.602 & 65.511 & 9.815 & 0.101 & 152.692 \\
Radial basis function & 14.430 & 28.627 & 68.883 & 9.982 & 0.102 & 151.286 \\
Ordinary kriging & 14.085 & $\mathbf{2 7 . 6 0 9}$ & $\mathbf{6 4 . 7 7 9}$ & $\mathbf{9 . 5 4 5}$ & 0.099 & 146.145 \\
Simple kriging & $\mathbf{1 4 . 0 6 5}$ & 27.703 & 65.167 & 9.555 & $\mathbf{0 . 0 9 8}$ & 146.474 \\
Universal kriging & 14.126 & 27.625 & 64.900 & 9.576 & 0.099 & $\mathbf{1 4 5 . 2 4 5}$ \\
\hline
\end{tabular}

\section{Calculation of water quality index (WQI)}

Groundwater quality status is quite significant to evaluate the potential regions of good or poor water quality. Spatial distribution of each water quality parameter provides a pictorial view of measured and estimated sample data values. However, WQI indicates permissible limits of drinking water quality standards at a general scale for an absolute assessment of groundwater quality scenario in a region. Commonly weighted overlay analysis is being used to calculate water quality index in most of current studies (Acharya et al., 2018; Kumar et al., 2013; Mahmood et al., 2016). In weighted overlay method weights assign to each groundwater quality parameter as per their relative importance over each other. It is prerequisite that sum of weighted values of contributing groundwater quality parameters should be equal to 1 (in numbers) or 100 in percentage to generate WQI. According to the Mahmood et al. (2016), WQI for a certain region can be determined through a series of different steps. Input weights of each quality parameter have been computed by using the following expression given in Equation 1: 


$$
w i=\left\{W i / \sum_{i=1}^{n} W_{i}\right\} \times 100
$$

where $w_{i}$ and $W_{i}$ are input and relative weights respectively, and $n$ is the number of water quality parameters considered. Quality rate of each parameter was computed using Equation 2, by comparing measured and suitable values in the spatial analyst extension using raster calculator tool. The mathematical expression for the development of quality rating is:

$$
Q i=\left(\frac{C i}{S i}\right) \times 100
$$

Since $Q i$ stands for quality rating of ith parameter, Whereas $C_{i}$ is concentration of ith parameter in an individual sample and $S_{i}$ is the standard value of drinking water for ith parameter.

Further quality rates and weights of each water quality parameter have been taken into account according to Table 3, to calculate water quality index as follows:

$$
W Q I=\sum_{i=1}^{n}(\mathbf{w i} \times \mathbf{Q})
$$

Table 3. Weight and standard values for selected groundwater quality parameters

\begin{tabular}{c|c|c|c|c|c|c}
\hline Water quality parameter & $\begin{array}{c}\mathbf{C a} \\
(\mathbf{m g} / \mathbf{L})\end{array}$ & $\begin{array}{c}\mathbf{C l} \\
(\mathbf{m g} / \mathbf{L})\end{array}$ & $\begin{array}{c}\mathbf{H C O} 3 \\
(\mathbf{m g} / \mathbf{L})\end{array}$ & $\begin{array}{c}\mathbf{M g} \\
(\mathbf{m g} / \mathbf{L})\end{array}$ & $\mathbf{p H}$ & $\begin{array}{c}\mathbf{T D S} \\
(\mathbf{m g} / \mathbf{L})\end{array}$ \\
\hline Relative weight (Wi) & 2 & 3 & 3 & 2 & 4 & 6 \\
Input weight (wi) $\%$ & 10 & 15 & 15 & 10 & 20 & 30 \\
WHO standard (Si) & $75 \mathrm{mg} / \mathrm{L}$ & $250 \mathrm{mg} / \mathrm{L}$ & $120 \mathrm{mg} / \mathrm{L}$ & $50 \mathrm{mg} / \mathrm{L}$ & 8.5 & $500 \mathrm{mg} / \mathrm{L}$ \\
\hline
\end{tabular}

Results of calculated water quality index by using Equation 3 represents a range from good to poor water quality status of Lahore district. The range is classified in five equal interval classes according to the standards defined by WHO, which are given below in the Table 4.

Table 4. Recommended equal interval classes for each groundwater quality parameter

\begin{tabular}{c|c|c|c|c|c}
\hline No. of classes & Class-1 & Class-2 & Class-3 & Class-4 & Class-5 \\
\hline WQI Values & $<70$ & $70-84$ & $84-97$ & $97-110$ & $>110$ \\
Category & Good & Moderately good & Marginally good & Moderate & Poor \\
\hline
\end{tabular}

\section{Results and discussion}

\section{Spatial analysis of water quality parameters}

Continuous spatial surfaces of each groundwater quality parameter generated by different interpolation techniques, demonstrate some high and low potential areas. As per Table 2, kriging method with its different empirical models demonstrate optimized surfaces with least RMSE values. However, optimization of any method is completely depended on 
dataset in hand and may vary for a different set of sampling points. Final maps of each water quality parameters have been classified in five classes according to the drinking water quality standards provided by WHO. A brief analysis of measured and interpolated concentration levels of each groundwater quality parameters has been discussed below.

\section{Calcium}

Calcium is an essential component to regulate heart rhythms and control over blood clotting in human (WHO, 2009). In present scenario, the measured values of calcium ranges from $05 \mathrm{mg} / \mathrm{L}$ to $87.20 \mathrm{mg} / \mathrm{L}$ in the study area. Whereas the least values of less than 34 $\mathrm{mg} / \mathrm{L}$ have been observed at garden town near Punjab University. A comparison of different spatial interpolation methods for $\mathrm{Ca}$ suggests that simple kriging is producing the most reliable prediction surface with RMSE of 14.065. Spatial distribution of Ca shows that most of the study area lies within permissible and safe limits of the element's concentration in drinking water, i.e. approximately less than $34 \mathrm{mg} / \mathrm{L}$. However, a continuous central spot of values ranges from 45 to $57 \mathrm{mg} / \mathrm{L}$ can be observed near the Anarkali region as shown in Figure 3. This central spot has also been highlighted as a high concentration zone by previous studies done by Mahmood et al. (2016) and Mahmood and Tariq (2017). Maximum concentration values were measured at Napier road near Anarkali. A continuous spatial trend of estimated values ranges from $34 \mathrm{mg} / \mathrm{L}$ to $45 \mathrm{mg} / \mathrm{L}$, is emerging from northeastern edge of study area. A set of past studies refers to this trend as an influence of landfill site existing in the region (Butt and Ghaffar, 2012; Mahmood et al., 2016). Presence of municipal solid waste near water body increases the rate of leachate production and percolation through underlying sediments that ultimately contaminates groundwater (Mahmood et al., 2013; Mahmood et al., 2017). Present discussions manifest that this trend may lead towards subsurface lateral flow of contamination from eastern side of the aquifer.

\section{Chlorine}

Natural water contains an excess amount of chloride ions due to its high polarizable nature. Highly chlorinated water causes different infections like asthma and other dermatitis infections and may increase the risk of bladder cancer (NHMRC, 2011). Comparison of deterministic and stochastic spatial interpolation methods suggests that ordinary kriging provides precise spatial distribution of $\mathrm{Cl}$ than radial basis function with RMSE value equals to 27.609. In present case, minimum values of $\mathrm{Cl}$ concentration level have been found at the upper region of Baghbanpura. Whereas high concentration of $\mathrm{Cl}$ (approximately $260 \mathrm{mg} / \mathrm{L}$ ) found at Mozang nearer to Anarkali region. In general increase in concentrations of $\mathrm{Cl}$ in the region is due to increase of mineral content (Nas, 2009). Long distance lateral flow of groundwater towards the deepest aquifer near Anarkali allows subsurface materials to get mixed in the water and causes groundwater contamination (Mahmood et al., 2016). In general, spatial distribution of $\mathrm{Cl}$ shows that the concentration of $\mathrm{Cl}$ in the groundwater lies in acceptable range. A regular expansion towards north and south eastern domains of study area can be assessed through geographical representation of $\mathrm{Cl}$ as given in Figure 3.

\section{Bicarbonates}

Bicarbonates are water soluble in form of calcium and magnesium constituents, but their excessive quantities make water hard. Definite permissible guideline values have not been specified by WHO for bicarbonates but their concentrations more than $500 \mathrm{mg} / \mathrm{l}$ is usually 
not appreciated (Mohsin et al., 2013). In the study area the concentration level of bicarbonates has been observed from $94 \mathrm{mg} / \mathrm{L}$ to the maximum value $506 \mathrm{mg} / \mathrm{L}$ in 2016 . The comparison of deterministic and stochastic spatial interpolation methods for $\mathrm{HCO}_{3}$ suggests that ordinary kriging produces the more precise prediction surface with RMSE of 64.779. An overriding trend has been observed in the spatial distribution of bicarbonates over the study area. Spatial analysis of $\mathrm{HCO}_{3}$ indicates a peculiar profile of descending order of concentration levels from south eastern region (Gulberg) to north western region (Shahdara). Maximum concentration levels are estimated at Gulberg that lies in the south eastern region of Lahore. However, least quality measures have been evaluated near the areas of river Ravi and Shahdara region. In current scenario, unusual spatial behaviour of bicarbonates tends towards high rate of underground weathering of rocks. As geological conditions explain that study area is composed of bicarbonates which dissolves in moving water. Due to longer path distance, ratio of dissolving sub-surface materials becomes greater causing alkalinity rise in the source.

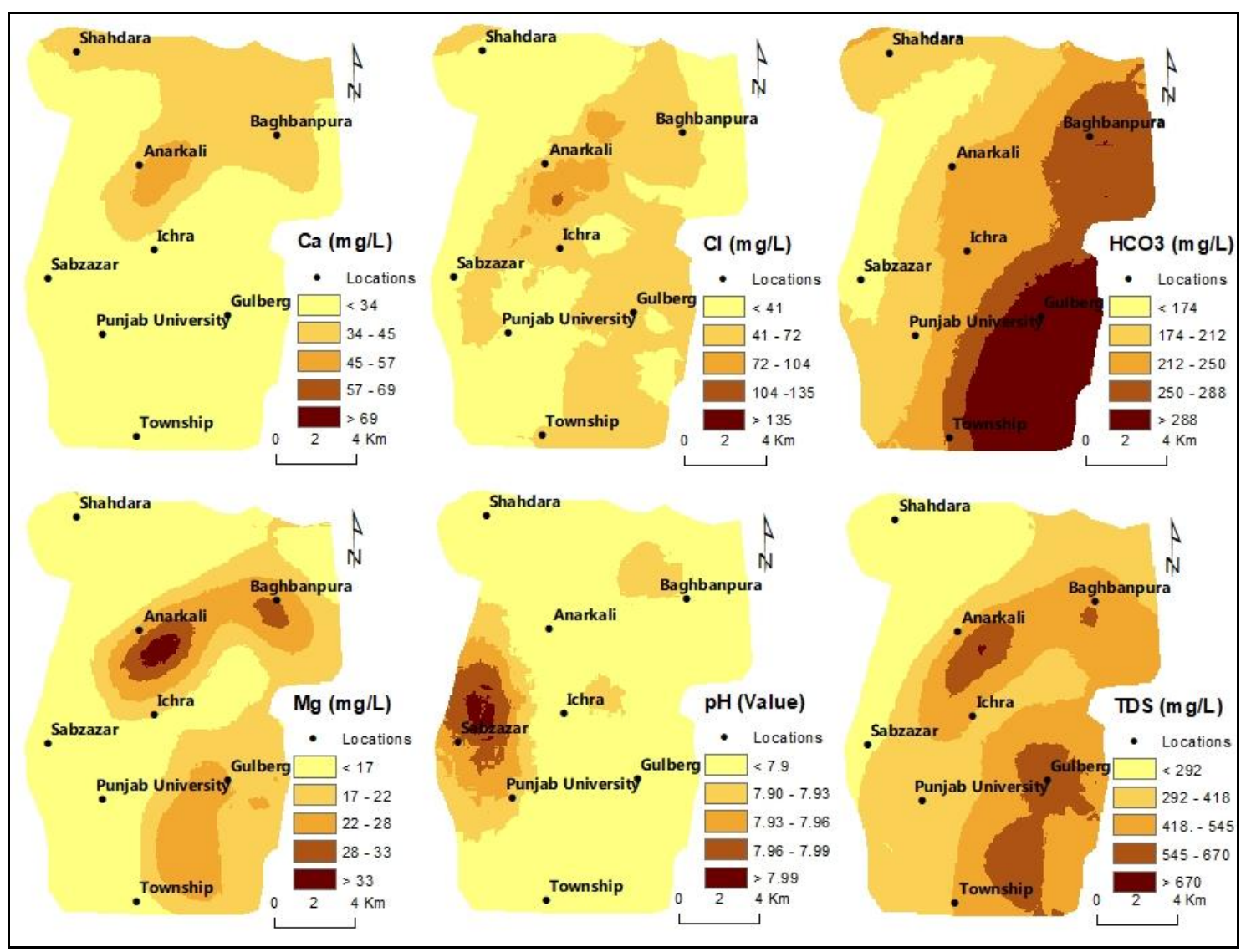

Figure 3. Spatial analysis of considered water quality parameters

\section{Magnesium}

Magnesium is most common component of natural water and usually exists in form of $\mathrm{Mg}^{+}$ion (WHO, 2009). Drinking water quality standards of Pakistan has specified approximate concentration of $\mathrm{Mg}$ in drinking water that should not exceeds from $50 \mathrm{mg} / \mathrm{L}$. Quantitative measures show that the concentration of $\mathrm{Mg}$ over the study areas varies from $5.60 \mathrm{mg} / \mathrm{L}$ and $65.3 \mathrm{mg} / \mathrm{L}$ in the year of 2016. A comparison of different 
spatial interpolation methods for $\mathrm{Mg}$ suggests that ordinary kriging is producing the most reliable prediction surface with RMSE of 9.545. Least values were measured at Garhi Shahu, which located in the south of Baghbanpura, Lahore. However, spatial distribution of classified concentration data values shows that minimal values of $\mathrm{Mg}$ exist over the region near Shahdara. Again, a prominent central spot has been observed at Anarkali region with high concentration of $\mathrm{Mg}$, approximately up to $65.30 \mathrm{mg} / \mathrm{L}$. Mahmood et al. (2016) identified the same trend for $\mathrm{Ca}$ and $\mathrm{Mg}$ in temporal analysis of groundwater quality from 2010 to 2013. Moreover, Mahmood et al. (2016) and Mahmood and Tariq (2017) have also reported this spot near Anarkali region as a permanent source of contamination. The same lowering of water table at centre of the study area is responsible for high concentrations of $\mathrm{Mg}, \mathrm{Ca}$ and $\mathrm{HCO}_{3}$ (Mahmood and Asim, 2017; Mahmood et al., 2016). In case of $\mathrm{Mg}$, a trend can be seen in the northeastern region near Baghbanpura, which illustrates a persistent range of concentration values from 22 to $28 \mathrm{mg} / \mathrm{L}$. Local influencing parameters like least permeable surfaces causes weathering of rocks. Usually untreated waste from different industries is disposed of into the river without any purification, which consequently raises magnesium concentration in running river water. As most of the studies conclude that the presence of both $\mathrm{Ca}$ and $\mathrm{Mg}$ cause temporary and permanent hardness in water.

\section{$p H$}

It is one of physical parameter which controls the presence of hydrogen ion in water. Low values of $\mathrm{pH}$ make water soft and high values tends to make water hard (WHO, 2007). An evident trend of $\mathrm{pH}$ values exists in the given dataset that ranges from 7.80 to 8.30 respectively. Comparison of different spatial interpolators shows that simple kriging provides more reliable surface for $\mathrm{pH}$ with RMSE of 0.098. Classification of spatial data reveals that $\mathrm{pH}$ concentration values below 7.9 have covered a large portion of the study area. Whereas, a continuous convergence of high concentrations of $\mathrm{pH}$, ranges from 7.99 to 8.30, towards the western centre of the study area, near Sabzazar has been observed, reflecting alkaline nature of groundwater as shown in Figure 3. This emerging spot is geographically located at the region where major drains (Babu Sabu and Gulshan-e-Ravi) of the city fall into the river Ravi. It has been asserted by Hamid et al. (2013) that inclusion of drain water into the river Ravi without any treatment is ultimately rising alkaline properties of river water. Baqar et al. (2014) has also investigated the impact of falling drains into river Ravi by using geospatial technologies with the conclusion that mean concentrations of total suspended solids were greater at the region closer Gulshan-e-Ravi outfall and region closer to it (Baqar et al., 2014). However, this impact is still at the closer regions of river Ravi. But in future it may expand towards the eastern areas of the study area. A range of 7.93 to $7.96 \mathrm{of} \mathrm{pH}$ levels have been observed near the regions of Baghbanpura and Ichra, reflecting presence of some temporary alkaline source across this region. Overall, $\mathrm{pH}$ values lie within their permissible limits suggested by WHO and PSQCA in the study area. But it should be noted that measured $\mathrm{pH}$ values range just below from the standard authorized values.

\section{Total dissolved solids (TDS)}

Natural water consists of different ionic constitutes in their specific amounts to made it saline (Atekwana et al., 2004). In Pakistan, the surface area is highly permissible, therefore concentrations of total dissolve solids in water is comparatively high. 
Although all the samples have been found within the safe limit suggested by WHO for TDS but a considerable range of $173.2 \mathrm{mg} / \mathrm{L}$ to $988.40 \mathrm{mg} / \mathrm{L}$ exists in drinking water of the study area. A comparison of different spatial interpolation methods for TDS suggests that universal kriging is producing the most reliable prediction surface with RMSE of 14.065. A notable trend in variation of classified data values, especially in the southern part of the residential area. At Ravi road and Shahdara concentrations of TDS have been estimated below $292 \mathrm{mg} / \mathrm{L}$. Whereas maximum concentration values have been found near Anarkali and Gulberg region, as can be identified through Figure 3. Total dissolve solids (TDS) is an important quality parameter which shows the measure of existing combinations of solid particles in accordance to lithology of examined groundwater samples. An emerging overriding trend in the current dataset of TDS shows a continuous spatial variation over the study area. It approves that Anarkali region and Gulberg have notable concentration levels of TDS. The prominent spatial affinity between Anarkali region and Baghbanpura also elevates a trend of contamination flow from north eastern side to south western edge. Gulberg has become the central commercial zone of residential area of Lahore due to the recent growth of modern infrastructure. Over extraction of groundwater has generated a depression zone in middle of city due to which degradation of water table is arising with the passage of time (Akhter and Tang, 2013; Kanwal et al., 2015; Mahmood et al., 2013). Usually, TDS rises in groundwater due to urban and rural runoff, desolation of natural sources, disposal of sewage and industrial waste into the rivers (Akhter et al., 2014).

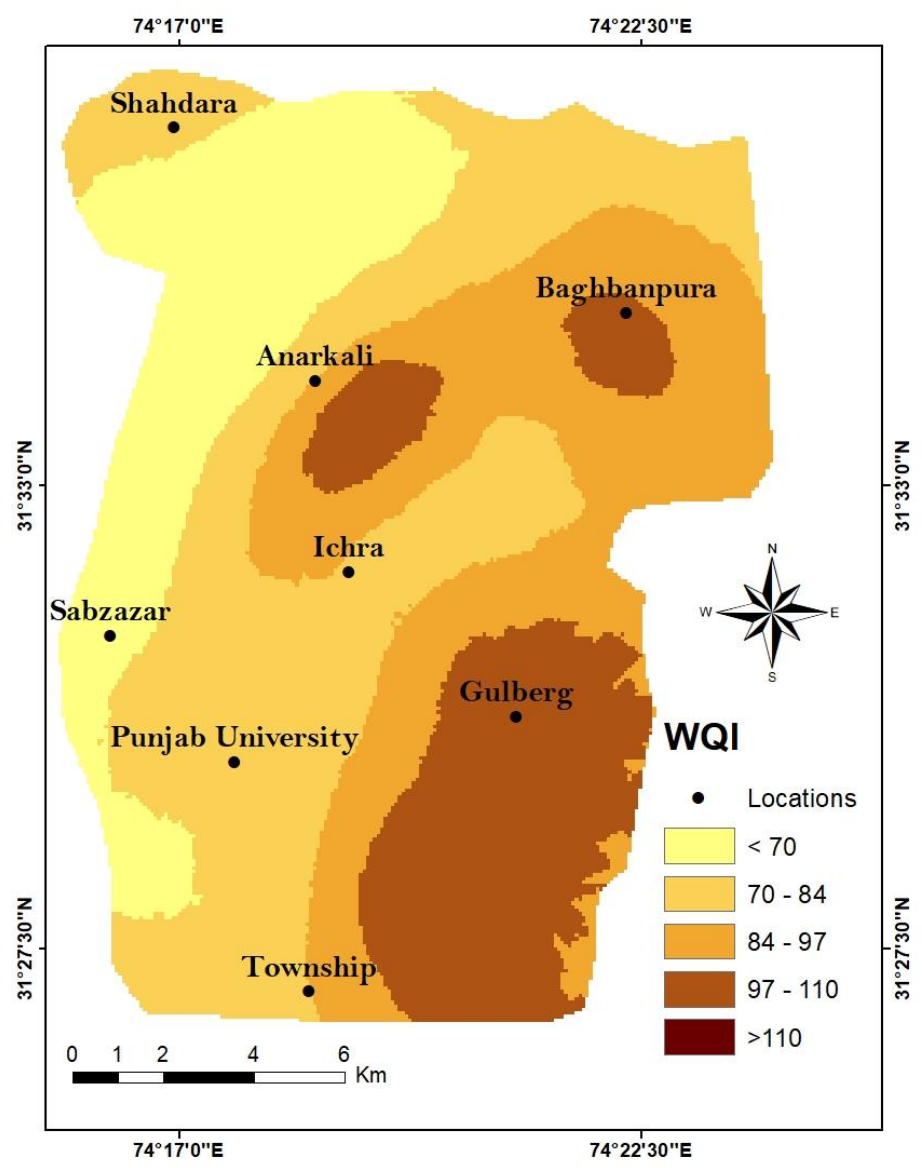

Figure 4. Spatial distribution of water quality index, classified as per WHO standards 


\section{Water quality index (WQI)}

Thematic maps of selected physical (TDS, pH) and chemical ( $\left.\mathrm{Mg}, \mathrm{Ca}, \mathrm{Cl}, \mathrm{HCO}_{3}\right)$ water quality parameters interpret spatial variability of their concentration levels at study area. Whereas, index map of groundwater quality shows current status of groundwater quality at any region, as given in Figure 4. Results of resampled interpolated rasters of current study have been classified in five equal number of classes. All the classes have been categorized as $<70$ (good), 70-84 (moderately good), 84-97 (marginally good), 97-110 (moderate) and >110 as highly poor water quality. In present scenario, almost whole residential area lies with in the categories of marginally good, moderate and poor water quality. Spatial analysis of WQI map indicates that Anakali region is prominent and permanent source of highly poor groundwater quality. Since previous studies have also revealed the consistent growth of concentrated zone of contamination across this region. Low recharge and high abstraction rates are exerting high pressure on the aquifer, particularly near Anakali region. High concentration level of groundwater quality parameters can be caused by ground lithology that is composed of carbonates of magnesium and calcium. Upper northeastern region of study area at Baghbanpura shows an order of "moderate" water quality. A couple of studies show that the seepage of contaminants from Mehmood Booti landfill site are effectively deteriorating the groundwater quality of Lahore (Butt and Ghaffar, 2012; Mahmood et al., 2014). Leachate transfers through porous soil layer and flows towards local aquifer with the aid of groundwater. Mahmood et al. (2016) infers that lowering of water table tends water to take relatively longer path to travel. As longer will be the path, greater will be possibility of dissolution of minerals (soluble ions) in to water, which ultimately rise the alkaline characteristics in groundwater. Areas exits in the northern edge (Shahdara, Sabzazar and Punjab University) shows almost good and moderately good water quality due to the availability of high recharge zone, but comparatively low consumption rate. In south eastern edge, high proportions of contamination have been estimated which evaluate the expansion rate of urban area. Rapidly growing population and modern ways of civilization are degenerating the availability of permeable surfaces as given above.

\section{Conclusion}

This study illustrates current status of groundwater quality in the second largest metropolitan city of Pakistan, named Lahore. GIS based spatial analysis has been found very useful and effective in studying potential regions of groundwater contamination as well as their spatial distribution over study area. Along with having an insight analysis of the spatial distribution of considered water quality parameters, i.e. calcium, magnesium, chlorine, $\mathrm{pH}$, bicarbonates and TDS, the WQI, as a sole representative of quality status, has been found very helpful in segregating water quality zones. Leaching through landfill sites (particularly Mahmood Booti) and disposal of industrial and municipal waste into river Ravi are major contributors of groundwater pollution in the area. WQI of 2016 along with previous similar studies of the region concludes that Anarkali region has become the permanent source of high contamination rate that is expanding towards the north eastern direction of study area. A directional impact of high concentrations from upper Baghbanpura region towards Anarkali region has been observed through TDS and WQI maps. High proportions of contaminants in groundwater under Anarkali could be due to dilution of calcium, magnesium and their 
carbonates that are abundant in underlying lithology. Deepest level of groundwater at Anarkali caused recharge water from outskirts of the area to flow towards it under gravity. As longer will be the travelling path for lateral flow of recharged water, more chances will be of soil-water interaction. Rapidly growing population and transforming of infrastructure in Lahore have lessened the availability of pervious land sites. Due to which south eastern region of study area explicitly shows high contamination ratios. Although, these factors generate temporary plumes in any concerned area but if unplanned infrastructure keep continues to develop, it will defiantly put long term effects on availability of safe groundwater. In general, groundwater quality of Lahore residential area is being deteriorating due to poor waste management system, involuntary developments in urban infrastructure, use of heavy pesticides in agricultural land surrounding the residential area and high-water extraction rates. Use of GIS based analysis in the study has highlighted potential regions of high concentrations of pollutants in the year of 2016, providing continuity of previous work done in this regard. Such a mapping of groundwater quality zones and their segregation can play a primary role in the decision-making process of local authorities for the sustainable solutions of drinking water in the region for which the only available source is the local groundwater. Therefore, this study concludes that an effective system for groundwater monitoring needs to be introduced by the local administrators and government authorities. Such issues are common in all over the developing world where lack of financial resources always hinder scientific knowledge-based solutions for sustainable development. Therefore, this study also concludes that the use of existing wells for sampling along with proper GIS can be an economical alternate in this regard.

\section{REFERENCES}

[1] Acharya, S., Sharma, S. K., Khandegar, V. (2018): Assessment of groundwater quality by water quality indices for irrigation and drinking in South West Delhi, India. - Data Brief 18: 2019-2028.

[2] Adnan, S., Iqbal, J. (2014): Spatial analysis of the groundwater quality in the Peshawar District, Pakistan. - Procedia Engineering 70: 14-22.

[3] Akhtar, M. M., Tang, Z. (2013): Identification of contamination sources and TDS concentration in groundwater of second biggest city of Pakistan. - International Journal of Environmental Science and Development 4(3): 341.

[4] Akhtar, M. M., Tang, Z., Mohamadi, B. (2014): Contamination potential assessment of potable groundwater in Lahore, Pakistan. - Polish Journal of Environmental Studies 23(6): 1905-1916.

[5] Akram, T., Gabriel, H. F. (2007): Urban Water Cycle Management of Lahore, Pakistan. ESDev - 2007, Second International Conference on Environmentally Sustainable Development, organized by COMSATS Institute of Information Technology, Abbottabad, Pakistan: 26-28 August, 2007.

[6] Asadi, S. S., Vuppala, P., Reddy, M. A. (2007): Remote sensing and GIS techniques for evaluation of groundwater quality in municipal corporation of Hyderabad (Zone-V), India. - International Journal of Environmental Research and Public Health 4(1): 45-52.

[7] Atekwana, E. A., Atekwana, E. A., Rowe, R. S., Werkema Jr, D. D., Legall, F. D. (2004): The relationship of total dissolved solids measurements to bulk electrical conductivity in an aquifer contaminated with hydrocarbon. - Journal of Applied Geophysics 56(4): 281294. 
[8] Azizullah, A., Khattak, M. N., Richter, P., Hader, D. P. (2011): Water pollution in Pakistan and its impact on public health- a review. - Environment International 37(2): 479-497.

[9] Baqar, M., Arslan, M., Mahmood, A. (2014): Characterization and load assessment of wastewater drains outfalls points into River Ravi, Lahore, Pakistan: an application of GIS. - The 9th National GIS Symposium in Saudi Arabia, at Sheraton Hotel \& Towers, Dammam-Eastern Province, pp. 1-15.

[10] Basharat, M., Rizvi, S. A. (2011): Groundwater extraction and waste water disposal regulation. Is Lahore Aquifer at stake with as usual approach? - Pakistan Engg. Congress; World Water Day, April 2011, pp. 112-134.

[11] Batool, R., Mahmood, K., Qimrah, H., Basit, I., Rubab, S. (2015): Selection of the optimal interpolation method for groundwater quality. - CASE 2015: Fourth International Conference on Aerospace Science \& Engineering, Islamabad, 2-4 September, 2015, pp. 325-333.

[12] Butt, I., Ghaffar, A. (2012): Ground water quality assessment near Mehmood Boti landfill, Lahore, Pakistan. - Asian Journal of Social Sciences and Humanities 1(2): 13-24.

[13] Chitmanat, C. Traichaiyaporn, S. (2010): Spatial and temporal variations of physicalchemical water quality and some heavy metals in water, sediments and fishes of the Mae Kuang River, Northern Thailand. - Int. J. Agric. Biol. 12: 816-820.

[14] Dogar, B. (2008): Lahore 20 Localities Getting Contaminated Water. - Newspaper "The Nations". http://www.lahorerealestate. com/ pakreale state times/showthread. php? tid = 413.

[15] Gunarathna, M. H. J. P., Kumari, M. K. N., Nirmanee, K. G. S. (2016): Evaluation of interpolation methods for mapping $\mathrm{pH}$ of groundwater. - International Journal of Latest Technology in Engineering, Management \& Applied Science 3: 1-5.

[16] Hamid, A., Zeb, M., Mehmood, A., Akhtar, S., Saif, S. (2013): Assessment of wastewater quality of drains for irrigation. - Journal of Environmental Protection 4(09): 937.

[17] Inter Press Service (IPS) (1999): Most Rivers in the World are Polluted. - Inter-Press Service, Washington, DC, pp. 38-41.

[18] Javari, M. (2017): Geostatistical modeling to simulate daily rainfall variability in Iran. Cogent Geoscience 3(1): 1416877.

[19] Kanwal, S., Gabriel, H. F., Mahmood, K., Ali, R., Haidar, A., Tehseen, T. (2015): Lahore's groundwater depletion - a review of the aquifer susceptibility to degradation and its consequences. - University of Engineering and Technology Taxila, Technical Journal 20(1): 26.

[20] Khattak, M. A., Ahmed, N., Qazi, M. A., Izhar, A., Ilyas, S., Chaudhary, M. N., Waheed, T. (2012): Evaluation of ground water quality for irrigation and drinking purposes of the areas adjacent to Hudiara industrial drain, Lahore, Pakistan. - Pakistan Journal of Agricultural Sciences 49(4): 549-556.

[21] Krishna Kumar, S., Karthikeyan, N., Sashikkumar, M. C. (2013): Surface water quality monitoring for Thamirabarani River basin, Tamil Nadu using GIS. - International Journal of Remote Sensing \& Geoscience (IJRSG) 2(3): 22-29.

[22] Kumar, P. J., Jegathambal, P., James, E. J. (2011): Multivariate and geostatistical analysis of groundwater quality in Palar River Basin. - International Journal of Geology 5(4): 108-119.

[23] Kumar, S. K., Karthikeyan, N., Sashikkumar, M. C. (2013): Surface water quality monitoring for thamirabarani river basin, Tamil Nadu using GIS. - International Journal of Remote Sensing \& Geoscience 2(3): 22-29.

[24] Mahmood, A., Muqbool, W., Mumtaz, M. W., Ahmad, F. (2011): Application of mulvariate statistical techniques for the characterization of groundwater quality of Lahore, Gujranwala and Sialkot (Pakistan). - Pak J Anal Environ Chem 12(1): 102-112.

[25] Mahmood, K., Tariq, F. (2017): Temporal GIS to access mature of groundwater contamination sources and importance of local recharge in Lahore Metropolitan, 
Pakistan. $-9^{\text {th }}$ Eastern European Young Water Professionals Conference, 24-27 May 2017, Hungary, pp. 97-98.

[26] Mahmood, K., Batool, S. A., Rana, A. D., Tariq, S., Ali, Z., Chaudhry, M. N. (2013): Assessment of leachate effects to the drinking water supply units in the down slope regions of municipal solid waste (MSW) dumping sites in Lahore Pakistan. - Int J Phys Sci 8(28): 1470-1480.

[27] Mahmood, K., Ali, S. R., Haider, A., Tehseen, T., Kanwal, S. (2014): Selection of the optimal interpolation method for groundwater observations in Lahore, Pakistan. Pakistan Journal of Scientific and Industrial Research 57(3): 154-166.

[28] Mahmood, K., Haq, Z. U., Batool, S. A., Rana, A. D., Tariq, S. (2016): Application of temporal GIS to track areas of significant concern regarding groundwater contamination. - Environmental Earth Sciences 75(1): 1-11.

[29] Mahmood, K., Batool, S. A., Chaudhary, M. N., Ul-Haq, Z. (2017): Ranking criteria for assessment of municipal solid waste dumping sites. - Archives of Environmental Protection 43(1): 95-105.

[30] Mendie, U. (2005): The Nature of Water. - In: Mendie, U. (ed.) The Theory and Practice of Clean Water Production for Domestic and Industrial Use. Lacto-Medals Publishers, Lagos.

[31] Mohsin, M., Safdar, S., Asghar, F., Jamal, F. (2013): Assessment of drinking water quality and its impact on resident's health in Bahawalpur city. - International Journal of Humanities and Social Science 3(15): 114-128.

[32] Montgomery, C. W. (2011): Environmental Geology. - McGraw-Hill, New York.

[33] Muhammad, A. M., Zhonghua, T. (2014): Municipal solid waste and its relation with groundwater contamination in Lahore, Pakistan. - Research Journal of Applied Sciences, Engineering and Technology 7(8): 1551-1560.

[34] Nas, B. (2009): Geostatistical approach to assessment of spatial distribution of groundwater quality. - Polish J. of Environ. Stud 18(6): 1073-1082.

[35] Nas, B., Berktay, A. (2010): Groundwater quality mapping in urban groundwater using GIS. - Environmental Monitoring and Assessment 160(1-4): 215-227.

[36] NHMRC (2011): Australian Drinking Water Guidelines Paper 6. National Water Quality Management Strategy. - National Health and Medical Research Council, National Resource Management Ministerial Council, Commonwealth of Australia, Canberra, pp. 7-5.

[37] Ojo, O. A., Bakare, S. B., Babatunde, A. O. (2007): Microbial and chemical analysis of potable water in public - water supply within Lagos University. - Afr. J. Infect. Diseases 1(1): 30-35.

[38] Pakistan Bureau of Statistics (2017): Population of Major Cities Census - 2017. Pakistan Bureau of Statistics, Islamabad.

[39] Postel, S. L. Daily, G. C., Ehrlich, P. R. (1996): Human appropriation of renewable fresh water. - Science 271: 785-788.

[40] Shabbir, R., Ahmad, S. S. (2015): Use of geographic information system and water quality index to assess groundwater quality in Rawalpindi and Islamabad. - Arab J Sci Eng 40: 2033-2047.

[41] Shah, Q., Abbas, H. (2017): Livelihoods and access to services: an analysis of peri-urban areas of Lahore, Pakistan. - Working Papers, eSocialSciences, https://EconPapers.repec.org/RePEc:ess:wpaper:id:12267.

[42] Sharaf, M. A. M, Subyani, A. M. (2011): Assessing of groundwater contamination by toxic elements through multivariate statistics and spatial interpolation, Wadi Fatimah, Western Arabian Shield, Saudi Arabia. - Int J Sci Eng Res 2(9): 1-14.

[43] Shrivastava, A., Tandon, S. A., Kumar, R. (2015): Water quality management plan for Patalganga River for drinking purpose and human health safety. - International Journal of Scientific Research in Environmental Sciences 3(2): 0071-0087. 


$$
\text { - } 3988 \text { - }
$$

[44] Siebert, S., Burke, J., Faures, J. M., Frenken, K., Hoogeveen, J., Doll, P., Portmann, F. T. (2010): Groundwater use for irrigation - a global inventory. - Hydrology and Earth System Sciences 14: 1863-1880.

[45] Sivakumar, R., Mohanraj, R., Azeez, P. A. (2000): Physico-chemical analysis of water sources of Ooty, South India. - Pollution Research 19(1): 143-146.

[46] WaterAid and BGS (2009): Groundwater Quality Sheet: The Impact of Urbanisation. Theme Sheets, British Geological Survey, Nottingham, UK, pp. 1-6.

[47] WHO and UNICEF (2013a): Joint Monitoring Programme: The Different Faces of Disparity in Access to Water and Sanitation. - UNICEF, WHO, New York.

[48] World Health Organization (2002): Quantifying Selected Major Risks to Health. In: WHO (ed.) The World Health Report. Reducing Risks, Promoting Healthy Life. - World Health Organization, Geneva, pp. 47-97.

[49] World Health Organization (2003): Guidelines for Safe Recreational Water Environments: Coastal and Fresh Waters. Vol. 1. - World Health Organization, Geneva.

[50] World Health Organization (2007): pH in Drinking-Water. Revised Background Document for Development of WHO Guidelines for Drinking-Water Quality. - World Health Organization, Geneva, pp. 1-2.

[51] World Health Organization (2009): Calcium and Magnesium in Drinking-Water: Public Health Significance. - World Health Organization, Geneva.

[52] World Wild Fund (2007): Water \& Health Related Issues in Pakistan. Lahore: Freshwater \& Toxics Programme. - WWF, Pakistan. 